\title{
The Effect of Fish Processing Waste on the Aquatic Environmental Condition and Community Income in the Tegalsari Beach Fishing Port Area, Tegal City
}

\author{
Marsya R. P. E. Jatiningtyas ${ }^{1 *}$, Supriharyono ${ }^{2}$, Suryanti $^{2}$ \\ ${ }^{T}$ Coastal Resource Management Study Program, Faculty of Fisheries and Marine Science, Diponegoro University, \\ Indonesia \\ ${ }^{2}$ Aquatic Resources Department, Faculty of Fisheries and Marine Science, Diponegoro University, Indonesia
}

*Corresponding Author

Marsya R. P. E. Jatiningtyas

\section{Article History}

Received: 13.05 .2020

Accepted: 26.05.2020

Published: 07.06.2020

\begin{abstract}
Tegal City, located in the North Coast of Java, is one of the areas that has experienced the development of fish processing industry activities, such as the home industry of fresh fish delivery, fish salting, fish fillets, fish meal making and others contained in the Block J. Area the large number of fish processing industries in the Block J area can have an impact on the environment and surrounding communities. These impacts can be either positive or negative. This study aims to determine the effect of the presence of fish processing waste on water quality that affects environmental conditions around the area of processing activities in depth. Raw materials for fish management production found in Tegalsari PPP (Coastal Fisheries Port) include: turmeric (Upeneus sulphureus), swangi (Priacanthus tayeneus), brown (Pomadasys macullatus), curator (Nemipterus nematophorus), peperek (Leiognathus bindus), and beloso (Saurida undosquamis). The fish processing waste contained in the Tegalsari PPP has a negative impact on workers, namely the total worker's income in the region does not experience a significant increase. In addition, fish processing waste contained in the Tegalsari PPP can be said to have polluted the surrounding environment. This is because some of the observed water quality parameters have a high pollution index. The results of water quality measurements that have been carried out (Table 1), can be recognized that the average water $\mathrm{pH}$ ranges from 7.61-8.08, DO 0.12-2 mg/l, TSS 810$1065 \mathrm{mg} / \mathrm{l}, \mathrm{NH} 3$ 0, 04-0.1 mg/l, BOD 10-30 mg/l, COD 44-90 mg/l, and oil-fat 194-344 mg/l.
\end{abstract}

Keywords: Waste, Environment, Revenue, Tegalsari.

\section{INTRODUCTION}

Tegal City, which is located on the North Coast of Java, is one of the areas that has experienced the development of fish processing industry activities, such as the home industry of sending fresh fish, salting fish, fish fillets, making fish meal and others. Most of the fish processing activities in Tegal City are in Tegalsari Sub-District, West Tegal Subdistrict, or around the Tegalsari Coastal Fisheries Port (PPP) area which is often referred to as Block J. The most productive fish processing activities in the Block $J$ area today are fish salting and fish fillets. These activities are included in the scale of micro and small industries whose production reaches 840 tons/year, with a total workforce of up to 1,675 people including fish carriers, weighers, cutters, and cleaners [1].

The accumulation of a large number of fish processing industries in the Block $\mathbf{J}$ area can have an impact on the environment and surrounding communities. These impacts can be either positive or negative. The existence of fish processing activities, have a positive impact on the local economy of the local community, and provide increased value in the promotion of the marine and fisheries sector. In addition to positive impacts, negative impacts that can be felt directly are the presence of waste from production. The development of industrial activities is accompanied by the development of the amount of waste produced. According to Prihatiningsih [22], each household marinating fish industry activity on average produces around 15-45 kg of solid and liquid fish waste every day. Wastes that can be produced from the fish

Copyright @ 2020: This is an open-access article distributed under the terms of the Creative Commons Attribution license which permits unrestricted use, distribution, and reproduction in any medium for non commercial use (NonCommercial, or CC-BY-NC) provided the original author and source are credited. 
processing industry include fish entrails, gills, mucus, scales, blood, fish washing water, and odors left behind. The waste is thought to be a problem and has an impact on the environment, especially water quality around the fish processing area which causes sanitation and environmental problems. Where only $0.2 \%$ of water in production is used to produce the product, $2 \%$ is experiencing watering, and the remainder is liquid waste. Waste generated from fish processing activities in the Tegalsari PPP area has not been managed optimally. This can be proven by the presence of solid waste left around the production area and the existence of WWTP buildings that are not used for a variety of reasons.

Research on the impact of fish processing waste in the Tegalsari PPP area has been conducted by several researchers namely Setiyono \& Wahjono [3] and Wibowo et al., [1]. According to the research results of Setiyono \& Wahjono [3], there are many fish waste treatment facilities from the fish fillet household industry that cannot operate, so there are several locations that experience waste pollution. According to the results of research by Wibowo et al., [1] liquid and solid waste from fish processing production processes is not well managed so it causes environmental pollution in the Tegalsari PPP area.

Based on the information above, there is a need for research that can examine the effect of fish processing waste on water quality that affects environmental conditions around the area of processing activities in depth. This is useful to provide an overview of the environmental management of the fish processing industry centers around the Tegalsari Coastal Fisheries Port (PPP) that is good and sustainable.

\section{Methods}

This study was conducted in Block J, the Tegalsari Coastal Fisheries Port (PPP) in Tegalsari Village (Figure 1.). This location was chosen because it is a center for the processing of fishery products in Tegal City. The data used in this study include primary data and secondary data. Primary data obtained from measurements in situ or directly and interview methods. In situ measurements are made in the waters around the area and observations in the laboratory. Direct measurement at the study site includes water sampling and measurement of water quality. The quality of supporting water taken is $\mathrm{pH}$ and DO. Data obtained from the results of laboratory analysis for water quality are TSS, NH3, BOD, COD, and oils and fats. Sampling is done once every 1 week in 3 consecutive weeks assuming the amount of processed fish production varies. The sampling point is divided into 3 points namely inlet channel (Station A), outlet (Station B), and river estuary (Station C). Water sampling is repeated 3 times at each station per sampling time. Secondary data collection techniques through document review.

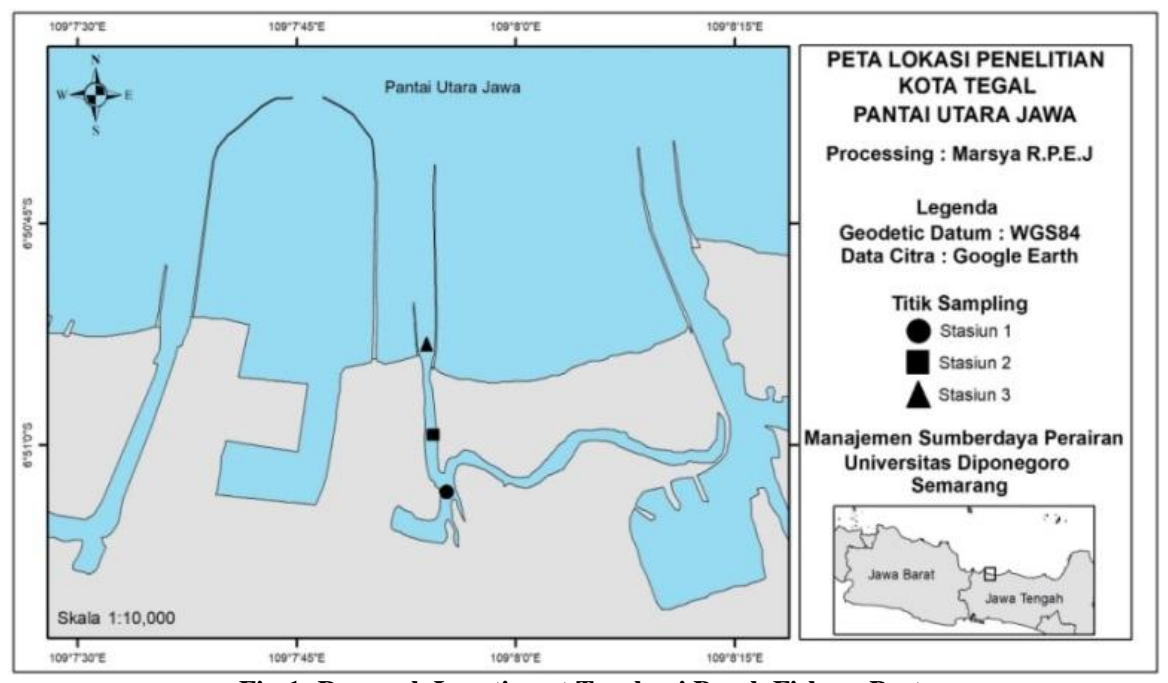

Fig-1: Research Location at Tegalsari Beach Fishery Port.

The identification of water quality at the study site was carried out using a pollution index. The parameters of the test results of field and laboratory measurements are then compared with water quality standards in the Government of the Republic of Indonesia Regulation No. 82 of 2001 concerning Water Quality Management. The pollution index calculation formula used in water quality analysis is as follows:

$$
P i j=\sqrt{\frac{\left(\frac{\mathrm{Ci}}{\mathrm{Li}}\right)_{\mathrm{M}}^{2}+\left(\frac{\mathrm{Ci}}{\mathrm{Lij}}\right)_{\mathrm{R}}^{2}}{2}}
$$


Description :

Pij = Pollution Index for designation (j)

$\mathrm{Lij}=$ concentration of water quality parameters stated in the water allotment quality standard ( $\mathrm{j}$ )

$\mathrm{Ci}=$ concentration of water quality parameters resulting from analysis

(Ci / $\mathrm{Lij}) \mathrm{M}=$ maximum $\mathrm{Ci} / \mathrm{Lij}$ value

$(\mathrm{Ci} / \mathrm{Lij}) \mathrm{R}=$ value of $\mathrm{Ci} / \mathrm{Lij}$ average yield

The pollution index obtained from the calculation results is then entered into the water quality status. The water quality status will explain whether the water is good, mildly polluted, moderately polluted or heavily polluted (Table 1).

Table-1: Status of Water Quality

\begin{tabular}{|c|l|}
\hline Pollution Index (IP) & Water Quality \\
\hline $0 \leq \mathrm{Pij} \leq 1$ & Good \\
\hline $1<\mathrm{Pij} \leq 5$ & Light Pollution \\
\hline $5<\mathrm{Pij} \leq 10$ & Medium Pollution \\
\hline $10<\mathrm{Pij}$ & Heavy Pollution \\
\hline
\end{tabular}

Analysis of the data used in this study is descriptive with a quantitative approach. In addition, water quality measurement data were analyzed using PCA (Principal Component Analysis) analysis. The significance of the difference is defined at $\mathrm{p}<0.05$. Statistical analysis was performed using SPSS 16 software.

\section{RESULTS AND DisCUSSION}

Based on the results of measurements of water quality that have been carried out (Table 1), it can be recognized that the average water $\mathrm{pH}$ ranges from 7.61-8.08, DO 0.12-2 mg / 1, TSS 810-1065 mg / 1, NH3 0 , 04-0.1 mg / 1, BOD 10-30 mg / 1, COD 44-90 mg / 1, and oil-fat 194-344 mg / 1. There are several parameters of water quality exceeding the established quality standards, namely DO, TSS, NH3, BOD, COD, and oil-fat at the study site. Then the pollution index is measured to determine the level of pollution measured from each water quality parameter. The results of the pollution index measurement are presented in Table 2.

Table-2: Results of Water Quality Measurement at Research Locations

\begin{tabular}{|c|c|c|c|c|}
\hline Water Quality Parameter & Station A & Station B & Station C & Quality standards \\
\hline $\mathrm{pH}$ & $7,7 \pm 0,2$ & $8 \pm 0,08$ & $7,6 \pm 0,01$ & $\mathbf{6 - 9}$ \\
\hline $\mathrm{DO}(\mathrm{mg} / \mathrm{l})$ & $0,17 \pm 0,05$ & $0,07 \pm 0,05$ & 0,2 & $\mathbf{3}$ \\
\hline $\mathrm{TSS}(\mathrm{mg} / \mathrm{l})$ & $867 \pm 57,7$ & $989 \pm 76,8$ & $911 \pm 19$ & $\mathbf{4 0 0}$ \\
\hline $\mathrm{NH}_{3}(\mathrm{mg} / \mathrm{l})$ & $0,04 \pm 0,04$ & $0,07 \pm 0,03$ & $0,06 \pm 0,01$ & $\mathbf{0 , 5}$ \\
\hline $\mathrm{BOD}(\mathrm{mg} / \mathrm{l})$ & $19,18 \pm 2,9$ & $31,7 \pm 13,6$ & $15,87 \pm 4,59$ & $\mathbf{6}$ \\
\hline $\mathrm{COD}(\mathrm{mg} / \mathrm{l})$ & $52,8 \pm 7,47$ & $90,4 \pm 3,81$ & $44,5 \pm 11,83$ & $\mathbf{5 0}$ \\
\hline Oil-Fat (mg/l) & $194,27 \pm 30,8$ & $344,21 \pm 63,5$ & $210,19 \pm 46,3$ & $\mathbf{1}$ \\
\hline
\end{tabular}

Table-3: Hasil Pengukuran Indeks Pencemaran pada Lokasi Penelitian

\begin{tabular}{|c|c|c|}
\hline Water Quality Parameter & Pollution Index Value & Water Quality \\
\hline pH & 1,47 & Cemar Ringan \\
\hline DO & 4,38 & Cemar Ringan \\
\hline TSS & 16,2 & Cemar Berat \\
\hline $\mathrm{NH}_{3}$ & 0,23 & Baik \\
\hline BOD & 8,45 & Cemar Sedang \\
\hline COD & 8,14 & Cemar Sedang \\
\hline Oil-Fat & 446 & Cemar Berat \\
\hline
\end{tabular}

\section{Production Raw Materials and Generated Waste}

The development of business and trade centers on the north coast of Java was followed by the development of several industrial activities. One is the processing of fishery products, such as: home industry fresh fish delivery activities, home industry fish fillet activities, home industry fish salting activities, fish flour manufacturing activities, and others. The currently most productive industry in Tegal City is the fish fillet industry. This is according to data from the Tegal City Maritime and Agriculture Office, the number of workers absorbed in the fish fillet business is estimated to reach 1,675 people, including fish carriers, weighers, cutters, and cleaners. Its production output reaches 840 tons/year which is sent to various major cities in Indonesia. Most of these industries are located in the Tegalsari PPP area. Production of several types of fish found at Tegalsari Beach Fishery Port in 2018 is presented in Table 4. 
Table-4: Fish Production in Tegalsari Beach Fishery Port in 2018

\begin{tabular}{|c|c|c|c|c|c|c|c|}
\hline \multirow[t]{2}{*}{ No. } & \multirow[t]{2}{*}{ Month } & \multicolumn{6}{|c|}{ Produksi (kg) } \\
\hline & & Kuniran & Swangi & Coklatan & Kurisi & Peperek & Beloso \\
\hline 1 & January & 40.250 & 23.475 & 23.355 & 38.025 & 0 & 4.675 \\
\hline 2 & February & 0 & 0 & 0 & 0 & 0 & 0 \\
\hline 3 & March & 244.430 & 208.135 & 92.665 & 225.525 & 0 & 48.105 \\
\hline 4 & April & 325.925 & 283.560 & 120.060 & 279.875 & 0 & 46.702 \\
\hline 5 & May & 204.175 & 179.800 & 51.750 & 185.875 & 0 & 24.680 \\
\hline 6 & June & 114.752 & 102.500 & 40.300 & 101.350 & 0 & 16.798 \\
\hline 7 & July & 79.750 & 72.950 & 13.675 & 66.400 & 0 & 8.375 \\
\hline 8 & August & 269.052 & 287.885 & 84.950 & 268.775 & 0 & 52.860 \\
\hline 9 & September & 244.601 & 256.920 & 98.105 & 272.476 & 0 & 37.710 \\
\hline 10 & Oktober & 217.750 & 212.325 & 69.870 & 229.200 & 0 & 36.240 \\
\hline 11 & November & 339.225 & 303.505 & 109.165 & 298.325 & 0 & 48.600 \\
\hline 12 & December & 232.088 & 201.875 & 106.000 & 223.628 & 0 & 37.631 \\
\hline & Total & 2.311 .998 & 2.132 .930 & 809.895 & 2.189 .454 & $\mathbf{0}$ & 362.376 \\
\hline
\end{tabular}

The raw materials used in this fish fillet business are non-economic fish found in Table 4. above. The types of fish include: kuniran (Upeneus sulphureus), swangi (Priacanthus tayeneus), coklatan (Pomadasys macullatus), kurisi (Nemipterus nematophorus), peperek (Leiognathus bindus), dan beloso (Saurida undosquamis) [4]. Types of fish Fish fillets are boneless fish meat slices, fish's entrails, and head as raw material for fish products such as tempura, meatballs, crackers, and so forth. Therefore, the process of fish processing still leaves waste, in the form of bones, stomach contents, and fish heads, which most of the waste producers process into fish flour as raw material for animal feed. The results of observations of several business units of the fish meal industry, most have not applied the principle of clean production, where the raw materials of fish originating from solid waste left over from the production of fish fillets in the form of bones, stomach contents and head of fish in the drying process are still openly dried. The traditional drying process by using sunlight in an open place causes a pretty strong odor, not only in the Tegalsari PPP area but also felt by most people around the area [1].

\section{Relationship of Water Quality Parameters}

The results of the Principal Component Analysis (PCA) analysis of environmental parameters in the Tegalsari PPP area can be seen in the Rotated Component Matrix table presented in Table 5.

Table-5: Rotated Component Matrix

\begin{tabular}{|c|c|c|}
\hline \multirow{2}{*}{} & \multicolumn{2}{|c|}{ Component } \\
\cline { 2 - 3 } & $\mathbf{1}$ & $\mathbf{2}$ \\
\hline COD & .781 & .538 \\
\hline BOD & .768 & .533 \\
\hline OIL-FAT & .774 & .544 \\
\hline TSS & .946 & .138 \\
\hline Ammonia & .948 & -.165 \\
\hline pH & .749 & .407 \\
\hline DO & -.934 & 102 \\
\hline
\end{tabular}

A map of the PCA analysis of environmental parameters in the Tegalsari PPP area from Table 5 data. The Rotated Component Matrix is presented in Figure 2.

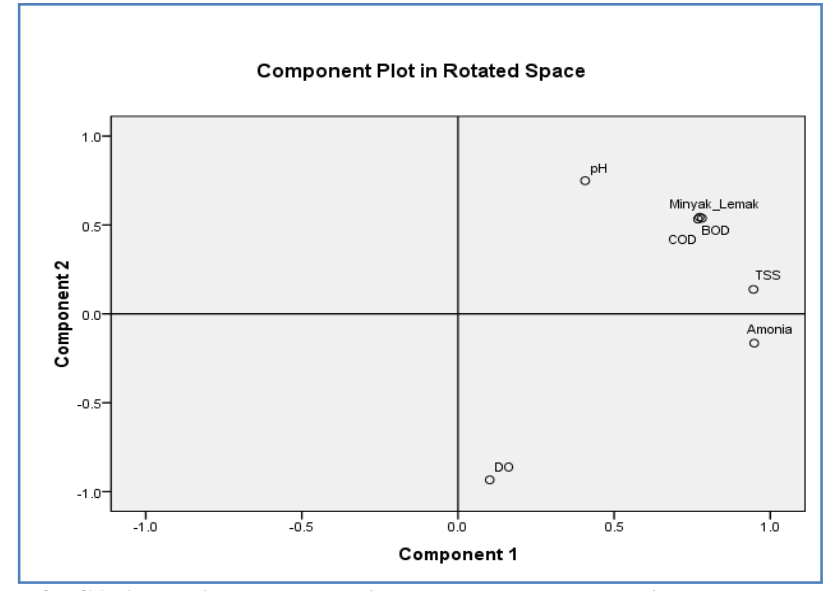

Fig-2: Map of PCA Analysis Results Environmental Parameters in the Tegalsari PPP area 
Based on the picture above, COD, BOD, Oil-fat, pH, TSS, Ammonia, and DO have a relationship. All environmental parameters other than DO have a positive correlation. This means that if the value of one of the five environmental parameters in the study site has increased, the others will also. Whereas DO will decrease if other environmental parameters increase and vice versa.

\section{Community Income Analysis}

Based on interviews conducted with informants, there are four main types of activities in the Tegalsari PPP. The main activities in the Tegalsari PPP are services, trade activities, activities of fisheries business activists and supporting activities.

Service activities are activities that are a success factor in port activities from upstream to downstream, these activities consist of the activities of fish rickshaws, fish carts, weighers, and loading and unloading. Trade activities are divided into two parts where upstream activities consist of fishing needs such as ice cube and clean depot workers, and downstream activities consist of small scale depot worker and fish seller activities. Activities of fisheries business activists consist of activities of fillet, dried fish, fish meal, and ship crew workers [5].

The existence of Tegalsari Beach Fishery Port has an impact on the opening of new jobs to serve the needs of port employees. Based on the explanation above, the existence of the Tegalsari coastal fishing port also has supporting activities. The information obtained from the Tegalsari PPP profile and sources, namely the head of the port, obtained supporting activities that occurred in the Tegalsari PPP area were the activities of self-funded shop houses, guards of public toilets, self-funded merchant stalls, and merchant stalls. A description of activities from upstream to downstream can be seen in Figure 3.

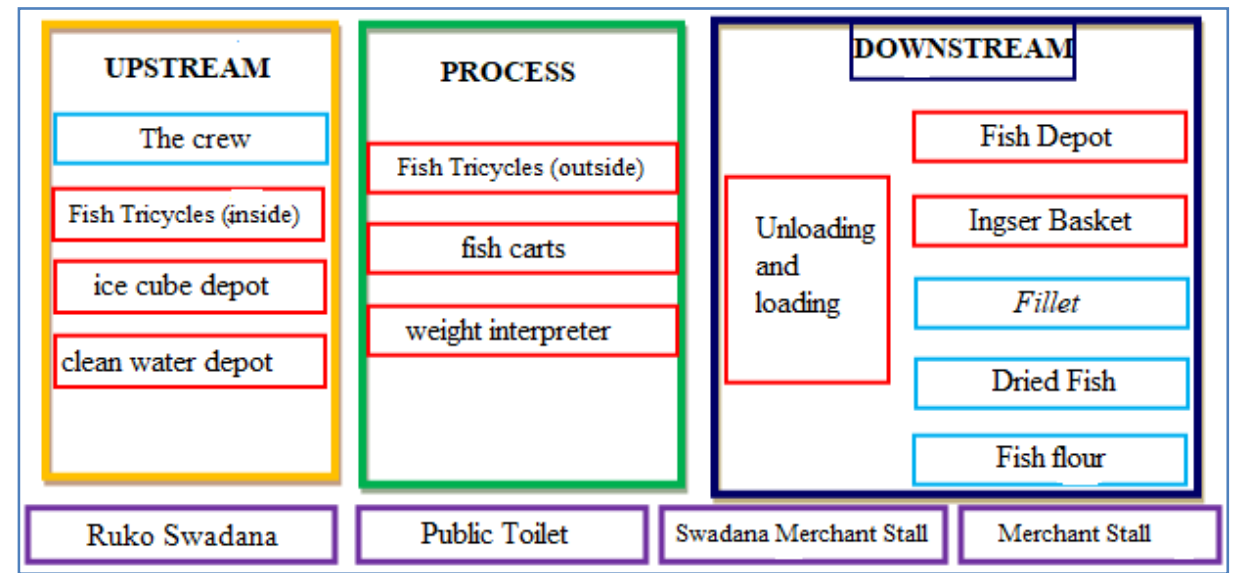

Fig-3: Upstream to Downstream Activities at Tegalsari PPP

\section{Descriptioin:}
$=$ Service activities
$=$ Activities of business activist workers
$=$ Supporting Activities

Based on the explanation above it can be seen that service activities in red are scattered in every port process from upstream to downstream. Trading activities in upstream activities are ice cube depot and clean water activities to fulfill the needs of fishing, and fish depot and collector basket activities as downstream activities where the activity sells fish from the sea. Activities of fisheries business activists with blue information consist of the fillet, dry fish, and fish meal industry workers included in the downstream activity category while the activities of ship workers or ship crews are contained in upstream activities. Supporting activities as a complement to Tegalsari's PPP activities with purple information are found in supporting facilities, namely self-financing shophouses, public toilets, self-funded merchant stalls, and merchant stalls. These activities consist of various types of activities from fishing equipment sellers to food stalls to provide food for workers.

The income that is the focus of the research is the income of respondents who work in the Tegalsari PPP area. Income is the maximum value that can be consumed by someone the same in a period at the end of the period [6]. Based on the analysis, the average income of respondents is different in each activity. Based on the results of the analysis of service activities have the largest average income with a nominal of Rp. 5,340,000.00. Supporting activities with an 
average income of Rp. 3,857,667.00. Trading activities with an average of Rp. 2,421,333.00, while the activity activists work with the lowest average of Rp. 1,850,000.00.

The $\mathrm{pH}$ value obtained at the time of the study was still in accordance with the range of $\mathrm{pH}$ values in the predetermined rules. According to Dojlido \& Best [21,22] that the $\mathrm{pH}$ of seawater is relatively more stable and usually in the range of 7.5 and 8.4, except near the coast. The ideal $\mathrm{pH}$ value for waters is $7-8.5$. Water conditions that are very basic or very acidic will endanger the survival of the organism because it will interfere with the metabolic process and respiration. Odum [7] added that the $\mathrm{pH}$ value between $6.5-8.0$ as a safe limit for the $\mathrm{pH}$ of waters for the life of the biota in it.

The range of DO values obtained is very low. Generally, the DO level in the water is at least $3 \mathrm{mg} / \mathrm{l}$. This is confirmed by Subarijanti [8] which states that the ideal oxygen content in water is between 3-7 mg/l. Almost all research stations have a DO value of $0 \mathrm{mg} / \mathrm{l}$. Salmin [9] states that the main source of oxygen in water comes from the photosynthesis of organisms that live in these waters, apart from the process of diffusion from free air. DO content in water is very related to the level of pollution, type of waste, and the amount of organic matter in water. Therefore, based on DO concentrations obtained, it can be estimated that the DO values at the study site are classified as severe pollution levels with DO values. The main cause of reduced levels of dissolved oxygen in water is caused by the presence of pollutants that can consume oxygen. The pollutant consists of organic and inorganic materials from various sources, such as animal and human waste, waste materials from industry and households. Most of the pollutants that cause reduced dissolved oxygen are organic waste [10].

The TSS value obtained has exceeded the TSS value range in the rules that have been carried out. This is expected to result in the acceleration of the deposition process at the study site. Suspended Solid (TSS) solid material is the place where heterogeneous reactions take place, which functions as the earliest precipitating material and can inhibit the ability to produce organic matter in water [11]. High TSS concentrations can also cause other impacts, as stated by Murphy [12] that high total suspended solids concentration values can reduce photosynthetic activity of marine plants both micro and macro so that the oxygen released by plants decreases and causes fish to die. This can result in a decrease in the quality of the waters around the Tegalsari PPP if TSS concentrations in river bodies continue to increase and flow into the high seas for a long time.

Based on the results of the research conducted, it can be seen that the value of ammonia obtained is still within the range of quality standards from applicable regulations. Although it is still in the normal range, please note that the ammonia levels in the waters if it exceeds the specified limit can cause dangerous pollution. High ammonia levels can be caused by several things, one of which is the amount of (organic) waste that enters the body of water. According to Apriyanti et al. [13], high levels of ammonia are due to the high content of urea and the ammonification process that comes from the decomposition of organic matter by microbes.

BOD value obtained has exceeded the value of the quality standard range that has been determined by applicable rules. This condition shows that the waters in the study site have been contaminated with quite a lot of waste. This was reinforced by Sugiharto [14] who stated that the greater the value of the BOD showed that the degree of wastewater contamination was greater. BOD value indicates the number of organic pollutants in river waters. The type of waste will determine the size of the BOD value. The type of liquid waste produced from the fish production process has organic material which is high enough to easily rot. BOD value is influenced by environmental factors that affect the activity of the microorganism itself. The more easily decomposition, the greater the BOD value. The process of decomposition of organic material in liquid waste is strongly influenced by water temperature because the activity of microorganisms is higher at increasing temperatures [15].

Based on the results of the study note that the COD value obtained has exceeded the specified quality standard threshold, so that the value can be considered high. According to Suparjo [4], the high content of COD can be caused by the degradation of organic and inorganic materials originating from community activities around rivers and the waste generated by industries that are not well-processed. Excessive COD content in water, as well as BOD content, will affect the decrease in dissolved oxygen (DO) and $\mathrm{pH}$, so that it will affect the decreasing water quality. A further consequence is the productivity of aquatic resources also declined. In addition, Boyd [16] states that the COD rate is a measure for water pollution by total organic substances both biologically decomposed, and which can only be decomposed by chemical processes. Oxygen needs are needed to oxidize organic materials both biodegradable and non-biodegradable.

The results of measurements of oil and fat that have been made, it is known that the value of oil and fat in the study location has not exceeded the specified quality standard threshold. Although it has not yet passed but the results of the study show the oil and fat content in these locations at a fairly high level. Oils and fats that enter the water and enough oxygen conditions will cause problems. Ketaren [17] states that there will be an oxidation process by air oxygen 
to unsaturated fatty acids in fat to form a volatile peroxide compound. Peroxides are toxic and if they enter the circulatory system they can cause a large need for vitamin E. Lack of vitamin E in fat will cause symptoms of encephalomalacia and cerebellar. In addition, the presence of oil and fat can affect water conditions, according to Hendrawan [18] the presence of oil layers on the surface of the water causes sunlight penetration and oxygen into the water to be reduced making it difficult for the work of decomposing microorganisms.

Based on the results of measurements that have been made, DO levels at the study site have very low values. This is because DO levels are used to decompose the waste that enters water bodies. Togatorop [19] states that BOD and COD that are far higher than the liquid waste quality standard will burden the environment. Dissolved oxygen in water bodies will be used to decompose the waste so that there will be an oxygen deficit. This is tantamount to killing plants or plants that live in the body of water which also requires dissolved oxygen for breathing. After an oxygen deficit occurs, there will be an overhaul of organic matter contained in the anaerobic palm oil industry waste. The problem is compounded by this anaerobic process because the organic matter will be broken down into greenhouse gases, namely methane gas and carbon dioxide gas. In addition, it will give off an unpleasant odor because the anaerobic process also produces $\mathrm{H}_{2} \mathrm{~S}$ gas.

Waste that enters the research station is generally in the form of organic materials such as fish processing waste, for example, water leftover from fish washing. Because it has not gone through a good management process so that it can affect the value of BOD and COD. According to Nuraini et al. [20], the presence of these organic materials causes BOD and COD values to be high within certain limits which can be toxic to ecosystems in the waters. Fish processing liquid waste that is not processed optimally can be one of the causes of environmental damage if it is discharged directly into the river in large quantities causing river water to become turbid and smelly, preventing the entry of dissolved oxygen into the water and can even cause the fish in the river to become intoxicated and die. Wastewater tends to reduce the quality of the environment such as water, air, soil, and all that is contained therein. In addition to that humans who use polluted water for bathing, washing, and even consuming river water can cause the emergence of various diseases including skin diseases as well as a disease transmission medium in the community. Water collection and disposal of wastewater that meets the health requirements needed to protect, maintain, and improve public health. unhealthy environment due to polluted wastewater can cause disruption to public health. Wastewater can be a breeding ground for pathogenic microorganisms that can transmit disease.

The results of the research that has been done can be seen that the presence of waste that is not managed properly has a negative impact on the income of the community around the PPP Tegalsari. According to information obtained from informants, the number of visitors who come is relatively reduced every day. Most of them complained about cleanliness and sanitation from the area around the Tegalsari PPP. In addition, the income earned by workers every year is not too significant. Based on the results of Diantoro \& Mussadun's [5] research on the analysis of workers' income in PPP Tegalsari service activities have the largest average income with a nominal value of Rp. 5,240,000, supporting activities with an average income of Rp. 3,787,333, trading activities with an average of Rp. 2,381,667, while the activity activists work with the lowest average of Rp. 1,811,667. The income results are not much different from the income results obtained in this study. The difference between the average income and the current income of workers, namely the service activities of Rp. 100,000.00. Supporting activities Rp. 70,334.00. Trading activities with an average of Rp. 39,666.00. Activities of business activists with the lowest average of Rp. 38,333.00.

\section{CONCLUSION}

The conclusion that can be obtained from the research that has been done is the raw material for fish management production contained in PPP Tegalsari, among others: kuniran (Upeneus sulphureus), swangi (Priacanthus tayeneus), coklatan (Pomadasys macullatus), kurisi (Nemipterus nematophorus), peperek (Leiognathus bindus), dan beloso (Saurida undosquamis) In addition, fish processing waste contained in the Tegalsari PPP has a negative impact on workers, namely the total worker's income in the region does not experience a significant increase. Fish processing waste contained in the Tegalsari PPP can be said to have polluted the surrounding environment. The range of water quality values measured during the study were TSS values ranging from $800-1033.33 \mathrm{mg} / \mathrm{l}$, pH values $7.46-8.06$, ammonia (NH3) values 0.037 - $0.098 \mathrm{mg} / \mathrm{l}$, BOD values 12.546 - $45.612 \mathrm{mg} / \mathrm{l}$, COD value $36,282-91,106 \mathrm{mg} / \mathrm{l}, \mathrm{DO}$ value 0 - 0,1 $\mathrm{mg} / \mathrm{l}$, oil-fat value $166,83-381,62 \mathrm{mg} / \mathrm{l}$. Water quality parameters that exceed specified quality standards are TSS, BOD, $\mathrm{COD}$, and DO. Water quality parameters that do not exceed quality standards are $\mathrm{pH}$, ammonia, and oil-fat, but the amount can be said to be quite high.

\section{Thank-you note}

We are thankful for the collaboration between Diponegoro University of Fisheries and Marine Sciences, Tegalsari Beach Fisheries Port, Tegalsari Village Government, and fisheries processing and market communities in the $\mathbf{J}$ Block of Tegalsari region who helped complete this research. 


\section{REFERENCES}

1. Wibowo, T. S. (2013). Pengelolaan Lingkungan Industri Pengolahan Limbah Fillet Ikan.

2. Prihatiningsih, K., I. Silviana, dan, N. Wandasari. (2015). Hubungan Perilaku Pengolahan Limbah dengan Sanitasi Lingkungan Kerja Fisik pada Industri Ikan Asin di Pengolahan Hasil Perikanan Tradisional (PHPT) Muara Angke, Pluit, Jakarta Utara Tahun 2014. Jurnal Forum Ilmiah XII(1), 77-86.

3. Setiyono, S., \& Wahjono, H. D. (2006). Pengelolaan Limbah Kawasan Industri Kecil di Kota Tegal. Jurnal Air Indonesia, 2(2).

4. Suparjo, M. N. (2009). Kondisi pencemaran perairan sungai Babon semarang. SAINTEK PERIKANAN: Indonesian Journal of Fisheries Science and Technology, 4(2), 38-45.

5. Diantoro, A., \& Mussadun, M. (2015). Pengaruh Pelabuhan Perikanan Pantai Tegalsari terhadap Kesejahteraan Pekerja. Jurnal Wilayah dan Lingkungan, 3(1), 1-14.

6. Rustam. (2002). Pendapatan menurut Standar Akutansi Keuangan No.23. Medan : Fakultas Ekonomi Jurusan Akutansi Universitas Sumatera Utara.

7. Odum, E. P. (1971). Fundamentals of Ecology. Philadelphia: W. B. Sounders Company Ltd.

8. Subarijanti, H. U. (2005). Pemupukan dan Kesuburan Perairan. Fakultas Perikanan. Malang: Universitas Brawijaya.

9. Salmin. (2005). Oksigen Terlarut (DO) dan kebutuhan oksigen biologi (BOD) sebagai salah satu indikator untuk menentukan kualitas perairan. Oseana. $X X X(3), 21-26$.

10. Connell, D. W., \& Miller, G. J. (1995). Kimia dan Eko-toksikologi Pencemaran. Jakarta: Indonesia University Press.

11. Tarigan, M. S. (2003). Edward,“. Kandungan Total Zat Padat Tersuspensi (Total Suspended Solid) Di Perairan Raha, Sulawesi Tenggara," Makara Sains, 7(3).

12. Murphy, S. (2007). General Information on Solids. City of Boulder/USGS Water Quality. Monitoring. Available from: http:// bcn.boulder.co.us/basin/data/BACT/info/TOTAL SUSPENDED SOLID.html. Nov 23. 2019.

13. Apriyanti, D., Santi, V. I., \& Siregar, Y. D. (2013). Pengkajian Metode Analisis Amonia Dalam Air Dengan Metode Salicylate Test Kit. Ecolab, 7(2), 60-70.

14. Sugiharto. (1987). Dasar-Dasar Pengelolaan Air Limbah. Jakarta: Universitas Indonesia Press.

15. Pamungkas, M. O. A. (2016). Studi pencemaran limbah cair dengan parameter BOD5 dan pH di pasar ikan tradisional dan pasar modern di kota Semarang. Jurnal Kesehatan Masyarakat (e-Journal), 4(2), 166-175.

16. Boyd, C.E. (1990). Water Quality in Ponds for Aquaculture. Birmingham Publishing Co. Birmingham, Alabama.

17. Ketaren, S. (1986). Pengantar Teknologi Minyak dan Lemak Pangan. Jakarta: UI Press

18. Hendrawan, D. (2008). Kualitas air Sungai Ciliwung ditinjau dari parameter minyak dan lemak. Jurnal Ilmu-Ilmu Perairan dan Perikanan Indonesia, XV(2), 85-93.

19. Togatorop, R. (2009). Korelasi Antara Biological Oxygen Demand (BOD) Limbah Cair Kelapa Sawit Terhadap pH, Total Suspended Solid (TSS), Alkaliniti dan Minyak/Lemak. Thesis, Medan: Universitas Sumatera Utara.

20. Nuraini, E., Fauziah, T., \& Lestari, F. (2019). Penentuan Nilai BOD dan COD Limbah Cair Inlet Laboratorium Pengujian Fisis Politeknik ATK Yogyakarta. Integrated Lab Journal, 7(2).

21. Dojlido, J., \& Best, G. A. (1993). Chemistry of water and water pollution. Ellis Horwood Limited.

22. Peraturan Pemerintah Republik Indonesia Nomor 82 Tahun 2001 tentang Pengelolaan Kualitas Air. 